\title{
ONLINE MARKETING PARTNERSHIP APPLICATION USING THE CONCEPT OF BUSINESS MODEL CANVAS
}

\author{
Jajat Sudrajat ${ }^{1 *}$, Meiryani, ${ }^{1}$ \\ ${ }^{1}$ Management Department BINUS Business School Undergraduate Program, \\ Accounting Department, Faculty of Economics and Communication \\ Bina Nusantara University Jakarta, Indonesia 11480 \\ *jsudrajat@binus.edu
}

\begin{abstract}
The purpose of implementing the long-term Community Service Program in the program is to produce a partnership model with Online Marketing Partnership Application using the concept of Business Model Canvas. This strategy is conducted to build partnerships with related parties that can increase success in the sector of Small and Medium Enterprises Silver Crafts by implementing strategies through online marketing of products. This Online Marketing Partnership application aims to accelerate the development of silver craftsmen in the village so as to increase sales. The method to be used is fact finding, in addition to collecting data in literature, also conducting interviews to Silver Craftsman owners and survey of business processes in order to collect supporting data. The output of this research is the Application of Online Marketing Partnership, one of which is a dynamic website that can be managed by Silver Craft Partners as a means of product promotion, besides through the website development of Silver Crafts Partners can receive orders from customers. Successful orders and transactions will be directly recorded through the sales transaction application.
\end{abstract}

Keywords: Partnerships, online marketing, applications, sales transactions

\section{INTRODUCTION}

The Village Development Partnership Application as one of the solutions to the wishes of President Jokowi, he wanted "Work-intensive Acceleration of 2018 Village Funds". The government accelerates labor-intensive village development programs. In a limited meeting the Working Cabinet led by President Joko Widodo finally agreed on eight steps so that the program was immediately realized in the field. The eight points of the agreement consist of point 1. Finalization of the 4 Ministerial Joint Decrees (SKB) to encourage labor-intensive rural development. The four ministers consist of the Ministry of Finance, Ministry of National Development Planning / National Development Planning Agency. Ministry of Home Affairs, and Ministry of Village PDTT. Point 2 Revision of LKPP (Government Agency for Procurement of Goods / Services).Head Regulation No. 13/2013 concerning Guidelines for Procedures for Procurement of Goods / Services in the Village to facilitate village selfmanagement. Point 3, Revised Minister of Finance Regulation No. 112/2017 to accelerate the distribution of village funds. Point 4, Determination of priority in the use of village funds consisting of a minimum of $30 \%$ of village funds for labor wages, labor covering all poor households, and using a minimum of $70 \%$ of local materials. Point 5, Acceleration of village fund disbursement Phase I in March 2018 and Phase II in June 2018. Item 6, Determination of work wages in rural labor intensive activities is $80 \%$ of the provincial minimum wage paid daily or weekly. Point 7 , Work wages and simple reporting models for labor intensive activities. Stipulated by regent regulation no later than March every year. Point 8, Encourages the national movement for the development of Leading Products in Rural Areas. The government has disbursed Rp 180 trillion allocated for village funds from 2014 to 2018. The Village Minister, Development of Disadvantaged Regions, and Transmigration Eko Putro Sandjojo said the funds were used to build infrastructure in the village. The development is intended to improve the living standards of rural residents (Kompas, 2018).

Based on the president's wishes and followed up by supporting programs in various ministries, we as lecturers will develop innovation in the implementation of the Community Service Program. Based on observations on 17-18 January 2018 in the village of Pasirmulya Banjaran Bandung, where 
in the village apart from Coffee as the flagship product of Mount Puntang tourist area, there were also several SME shoe-making, convection, silver handicrafts. Currently we have succeeded in making a prototype of the Business Model Application, for students to use as one of the learning media for students to dare to venture in the business field, so that students hope to collaborate with lecturers in the Community Service Program. The research results understand that combining various learning theories and approaches in order to promote entrepreneurial awareness and mind-set. It is also necessary for entrepreneurship education to be student-centred and focused on life experience and practice learning, so that a variety of theoretical learning can be combined with practice experience (San Tan and $\mathrm{Ng}, 2006$ ). We as lecturers want to contribute as agents of change, where the heart and spirit of higher education are in the lecturers. The knowledge, quality, enthusiasm, spirit, ethos, and dedication of the lecturers in transferring knowledge and skills to students as well as arranging the mindset and dissemination of the values of science and the values of a whole life are vital. This task can only be done by lecturers. Not by the education bureaucracy. Exemplary and seriousness of the lecturer in carrying out their duties is very important in shaping the mindset and patterns of student behavior. The mindset and behavior of lecturers are reflected in implementing the Tridarma of higher education, namely education, research and community service. Lecturers must research and carry out community service activities, don't just teach. Lecturers are the key in developing and printing quality (JPP, 2018). Lecturer and student collaboration in the community service program will be more optimally implemented, so that High educational institutions should consider producing entrepreneur graduates. Entrepreneurship education in college must be fully reviewed and changed. Clear goals should be established on developing entrepreneur-oriented graduates, so that the education process will require a lot of restructuring to improve the development of entrepreneurship skills (Taatila, 2010).

\section{Partner Profile Analysis}

Based on the observations we made on January 17-18, 2018, the potential for the development of Leading Rural Products ( is Coffee, because currently these products have been exported, and even become one of the most expensive coffees in the world (information from President Joko Widodo's Video), although there are other products such as Silver Crafts, Shoes and Convection. The Pasirmulya village currently has the PLP-BK community (Structuring the Community-Based Settlement Environment.

\section{Partner Problems}

At present the fundamental problems experienced by SMEs in Pasirmulya Village are as follows: Silver Craft UKM, currently the market is sluggish, craftsmen produce based on orders from Wholesale Stores in Jakarta

1. UKM Shoes, most of them have been producing with designs according to their orders, not yet having a brand

2. Convection SMEs, production based on orders and not having a brand.

3. Coffee SMEs, there are already several brands, namely "Kopi Wangun", "Kopi Haben Nagen", but not yet optimal in marketing.

4. Coffee farmers, have not felt an increase in income even though the price of coffee from Mount Puntang is the most expensive coffee in the world.

5. There is no website for Village Owned Enterprises (BUMDes), as a management center for SMEs and Farmers.

\section{Problem Solving Solution}

"Work Solid Acceleration of 2018 Village Funds", is one of the solutions to accelerate the problems of SMEs and farmers, this can be done supported by technology media so that information delivery is faster and more accurate, information management requires good technology, because information is one of the very important for a company or institution. The Village Development Partnership Application which is supported by internet media can be relied upon to quickly disseminate information from all activities or transactions in all fields. The problems of SMEs and Farmers in Pasirmulya Village can be overcome through increasing partnerships, especially in the field of marketing, so that partnership partnerships with various educational institutions, the government and the private sector can be done more quickly through the Government to accelerate labor-intensive rural 
development programs. This application will be centered on the Village Owned Enterprise (BUMDes) institution.

To map various problems, especially SMEs, where one problem is the lack of customers or partners. We will begin solving problems about partnerships, because the partnership is one of the concepts of the Business Model Canvas, which consists of nine interconnected parts, one of which is the "Key Partners" section. So that the concept of Business Model Canvas provides students and SMEs with experience for business simulation so that a combination of practice and theory experiences can be integrated. Other research results suggest that entrepreneurship intentions for graduates are very low compared to working in companies, they are more interested in working first so that establishing the company will be done as they have experience. This appeals to curriculum makers and policymakers so that it becomes important information for the development of entrepreneurship education in the future. The positive effects of entrepreneurship education on the future plan of graduates to start a business are possible through independent selection so that the quality of educational content is entrepreneurial in terms of academic and teaching content as well learning methods require further attention. This would make more sense for some students to take entrepreneurial education comprehensively (San Tan and $\mathrm{Ng}, 2006)$.

Transaction activities that are carried out dynamically through internet media are very possible for parties who do not have to meet each other or face to face. Goods or service needs in Pasirmulya village can be known quickly, so that partners in other regions can find out and provide services, on the contrary the superiority of other village area products can be known quickly so that Pasirmulya village can obtain the necessary goods and services, is also expected to accelerate the movement national development of Leading Rural Area Products (Prukades) in various villages. This provides benefits for SMEs and Farmers as well as related agencies in saving time and energy. The government wants social media (Medsos) to be used for productive things, encouraging creativity and innovation, and improving people's welfare (Kemeninfo, 2018)

Based on the description above, the Village Development Partnership Application Program can provide alternative solutions to problem solving to overcome marketing problems by utilizing internet media technology with one of the dynamic website uses to reach a wider market so that it is expected to increase sales turnover from SMEs that.

In addition to the application, we will provide training in bookkeeping / accounting management, because whatever the form of business and the amount of capital owned, making financial reports or bookkeeping is a must. With bookkeeping, every business activity will be recorded properly which can be used as a barometer and indicator to determine the company's performance being carried out to support more productive, efficient and effective financial processing that can increase profit or profit (Rianti, Swadarma. 2012). After attending the training, it is expected that SMEs can develop business management skills. Business skills can be learned through the Business Model Canvas so that students and SMEs managerial competencies will develop, in particular, the relationships between entrepreneurial managerial competencies such as administrative, knowledge and technology competencies, network building competencies, communication skills, business development models and financial. (Motahareh and Sung, 2017). 


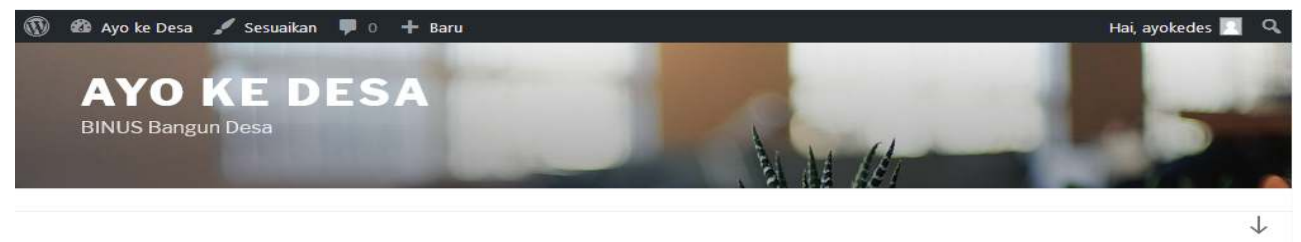

Pos
Agustus 28, 2018 sunting
Kerajinan Perak

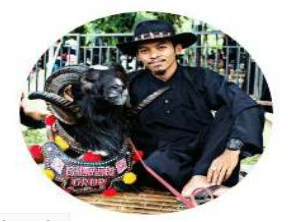

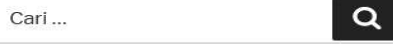

POS-POS TERBARU

Kerajinan Perak

Desa Wisata Dusun Wangun

Proses Produksi Kerajinan Perak

Wisata Alam Kebun Kopi Gunung Puntang

Figure 1. Prototype Website

Source: Jajat Sudrajat, 2017

\section{METHOD}

Based on observations that have been made, generally SME partners are the main problem in the field of marketing, media promotion and marketing tools that are commonly carried out namely websites, currently not available, but some SMEs have used Android as a marketing communication medium. To overcome marketing problems, one solution is to use the Village Development Partnership Application (AKPD), in the form of websites and applications on android. In making this application will optimize the Android device as a marketing tool. In the implementation of the application, we will use the method of implementation by involving or collaborating with SME partners, in addition to displaying the product also displays the potential of good partnerships with fellow SMEs, government and private institutions and other institutions.

\section{CONCLUSION}

In overcoming the problem of Silver SMEs, where one of the problems is the market is sluggish and only depends on orders from wholesalers in the Tanah Abang market in Jakarta, the conclusion to overcome the problem is as follows:

1. Increase partnerships with several stores or wholesalers.

2. Improving management of business management, one of which is to tidy up the recording of purchases and sales, to measure and evaluate the development of sales or revenues periodically.

Both of these solutions can be done by using a partnership application with the Business Model Canvas concept, now a prototype partnership application has been started through the creation of the Ayokedesa website.

\section{REFERENCES}

Kompas, 2018. 4 Tahun Jokowi-JK, Rp. 180 Trililun Digelontorkan untuk Dana Desa.[Online]. Available in https://ekonomi.kompas.com/read/2018/10/24/125810526/4-tahun-jokowi-jk-rp180-triliun-digelontorkan-untuk-dana-desa [Accessed on October 25, 2018].

San Tan, S. \& Ng, C.K.F. (2006). A problem-based learning approach to entrepreneurship education. Education+Training, 48(6), 416-428. 
JPP, 2018. Menristekdikti: Dosen Wajib Lakukan Tri Dharma Perguruan Tinggi. [Online]. Available in . https://jpp.go.id/teknologi/pendidikan/320463-menristekdikti-dosen-wajib-lakukan-tridharma-perguruan-tinggi [Accessed on October 25, 2018].

Taatila, V.P. (2010). Learning entrepreneurship in higher education. Education+Training, 52(1), 4861.

Osterwalder, Alexander; Pigneur, Yves (2010). Business Model Generation: A Handbook for Visionaries, Game Changers, and Challengers. John Wiley \& Sons, Inc. New Jersey. ISBN: 978-0470-87641-1

Rianti, Swadarma (2012). Pembukuan Sederhana Usaha Dagang \& Jasa. Laskar AKSARA. ISBN: $602-7732-43-1$

Kementrian Komunikasi dan Informatika, 2017. Pemerintah ingin media sosial dimanfaatkan untuk hal produktif.[Online]. Available in https://kominfo.go.id/content/detail/8637/pemerintahingin-media-sosial dimanfaatkan- untuk-hal-produktif/0/sorotan_media. [Accessed on October 25, 2018].

Motahareh, Z. \& Sung, E.C. (2017) Relationship between entrepreneur's managerial competencies and innovate start-up intentions in university students: An Iranian Case. International Journal of Entrepreneurship, 21(3). 